\title{
Strategic Planning of Information Systems for Mosque in Indonesia
}

\author{
Galih Abdul Fatah Maulani, Teten Mohamad Sapril Mubarok \\ Universitas Garut \\ Kampus IV Universitas Garut jln. Terusan Pahlawan No. 32 Sukagalih, Garut - Jawa Barat, Indonesia \\ galihafm@uniga.ac.id
}

\begin{abstract}
Abstrak-Anticipating the era of Society 5.0, communities and organizations are required to have integrated and comprehensive information access, including the management of mosques in Indonesia. This study aims at providing a strategic planning in the form of a portfolio for future application of mosques management information system services. This study was conducted with reference to Ward and Peppard's strategic plan for information systems, which included SWOT analysis, critical success factor method and McFarlan's strategic grid. The results showed the mosque management must have several applications, mapped into 4 quadrants (strategic, high potential, key operation, and support). It is expected that this application portfolio can help managers of mosques in Indonesia provide faster, more accurate, and more accountable information.
\end{abstract}

Keywords- Strategic Planning; Information System, Mosque.

\begin{abstract}
Abstrak- Dalam memasuki era Society 5.0, masyarakat dan organisasi dituntut untuk memiliki akses informasi yang terintegrasi dan komprehensif, tak terkecuali manajemen di Mesjid-Mesjid Indonesia. Penelitian ini bertujuan untuk memberikan perencanaan strategis berupa portofolio aplikasi mendatang yang diperlukan oleh Mesjid untuk layanan sistem informasi yang lebih terarah sesuai dengan kebutuhan manajemen. Metode yang digunakan pada penelitian ini menggunakan metodologi perencanaan strategis system informasi versi ward-peppard. Metode tersebut menggunakan teknik analisis meliputi analisis SWOT, analisis Value Chain, metode Critical Succes Factors, metode Balanced Scorecard dan McFarlan's Strategic Grid. Hasil menunjukkan terdapat beberapa aplikasi dibutuhkan oleh manajemen Mesjid yang telah dipetakan menjadi 4 kuadran (strategic, high potential, key operation, and support). Sehingga diharapkan dengan adanya portofolio aplikasi ini, pihak pengelola masjid di Indonesia dapat lebih optimal dalam menyajikan informasi lebih cepat, akurat dan akuntabel.
\end{abstract}

Kata Kunci- Perencanaan Strategis; Sistem Informasi, Mesjid.

\section{INTRODUCTION}

Information technology has been indispensable for every organization, both profit and non-profit, in carrying out their business process [1]-[6]. Access to information is now highly demanded by the public, including in the management of places of worship such as mosques [7]. As a religious and social organization, mosques must be managed professionally [8] in a sense that information regarding the public funds must be controlled transparently and accountably. This issue needs to be accommodated in the strategic planning of information systems for mosques [9].

Mosques must be managed professionally to serve the public interest. To this end, comprehensive strategic planning of mosque information systems is required [10]. According to the Ministry of Religious Affairs of the Republic of Indonesia, there are approximately 800,000 mosques in Indonesia [11]. This implies that mosques play a massive role in di Indonesian society. Therefore, valid and accessible information is highly expected of mosque management by the community. This is the focal point of the present study.

\section{LITERATURE REVIEW}

Information Systems Strategic Planning is part of a strategic management field study that involves several components such as people, information technology, and organization [12]. But strategic planning for information systems is increasingly seen as a critical component of the corporate plan and an important focus area for good IT governance. Besides, information systems strategic planning has the role of a good business strategy organization. Therefore it has become a concern for academics and practitioners[13]-[15].

The concept of IS / IT strategic planning is the stages of the process of identifying a computer-based SI portfolio of applications so that it supports the organization in implementing its strategic business plan and realizing its business objectives. A framework that is often relevant today is using a framework developed by Ward and Peppard[16].

The use of methodologies in IS / IT strategic planning is to avoid the risk of failure, ensure the involvement of all interested parties and minimize 
individual dependency, and put more emphasis on the processes and targets determined

[17]. This Ward and Peppard version methodology approach starts from the investment conditions of IS / IT in the past that are less useful for the business objectives of the organization and capture business opportunities, as well as the phenomenon of increasing the competitive advantage of an organization because it can utilize SI / IT to the maximum. The lack of useful IS / IT investment for organizations is due to the strategic planning of IS / IT, which is more focused on technology, not based on business needs.

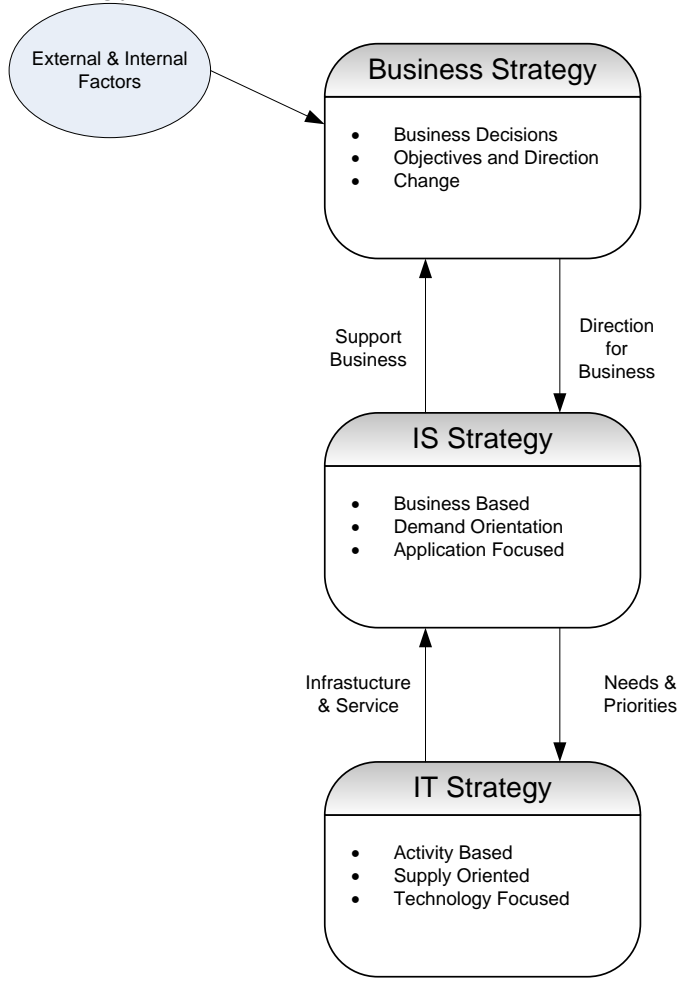

Figure 1 Relationship between Business Strategy, IS Strategy, and IT Strategy (Ward \& Peppard,). [3]

\section{METHODOLOGY}

The strategic planning of information systems in the present study was carried out using Ward and Peppard's model, as illustrated in. This is to reduce the risk of failures, ensure participation of all interested parties and minimize individual dependency, and emphasize the process and the achievement of the predetermined objectives [3].

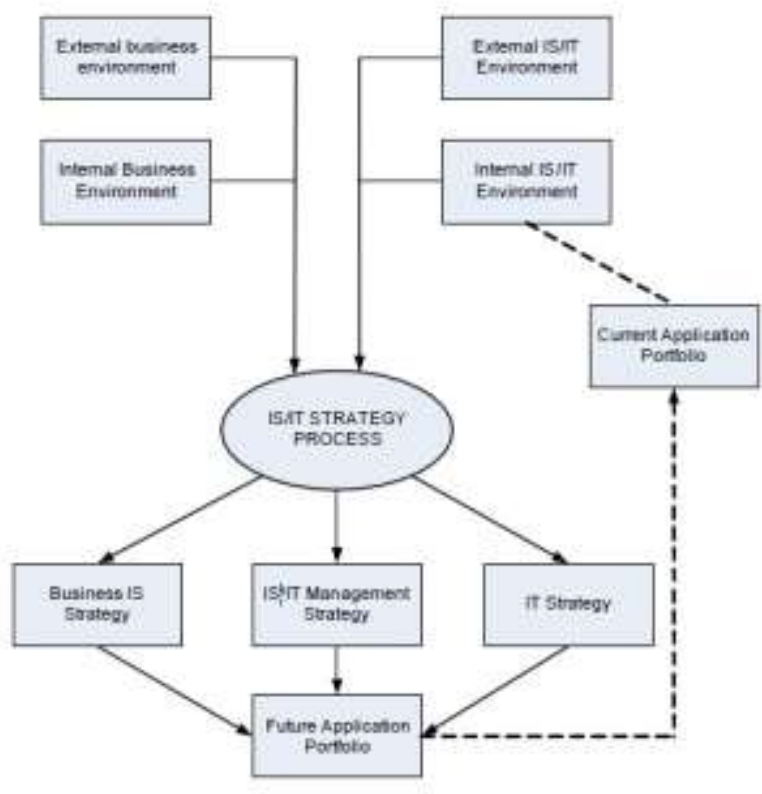

Figure 2. Framework Models of Ward and Peppard [18]

This model consists of two stages: input and output. The input stage consists of the following steps [2], [19], [20]:

a. Internal business environment analysis

b. External business environment analysis

c. Internal information system environment analysis

d. External information system environment analysis

The output stage consists of a business information system (IS) strategy, information technology (IT) strategy, IS/IT management strategy, and future application portfolio. The research objects were four mosque managers in Garut that have the same business process scale. Data were collected using observation, interviews, and documentary studies. Data analysis was SWOT analysis, critical success factor method, and McFarlan's strategic grid.

\section{RESULT AND DISCUSSION}

SWOT analysis was performed to examine the mosque business environments to identify IS opportunities and determine the IS strategy to achieve organizational competitive advantage. The results are presented in Table 1.

Table 1. Mosque SWOT Matrix 


\begin{tabular}{|c|c|c|}
\hline IFAS & \begin{tabular}{ll}
\multicolumn{2}{l}{ Strengths (S): } \\
a. & has sufficient \\
& infrastructure \\
b. & equipped \\
& with good \\
& Internet \\
& access \\
c. & has a solid \\
& and \\
& innovative \\
& work team \\
d. & located in a \\
& strategic \\
& campus \\
& environment \\
e. & has relevant \\
& human \\
resources
\end{tabular} & 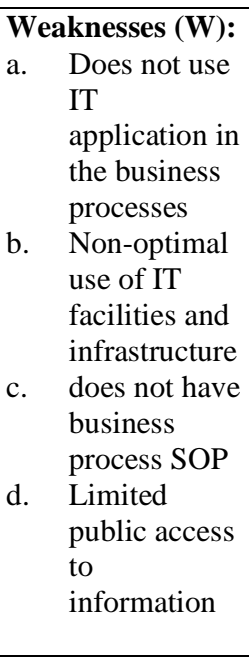 \\
\hline $\begin{array}{l}\text { Opportunities } \\
\text { (O): } \\
\text { a. Has public } \\
\text { support for } \\
\text { the mosque } \\
\text { development } \\
\text { b. Is an icon in } \\
\text { the } \\
\text { neighborhood }\end{array}$ & $\begin{array}{ll}\text { Strategy S-O: } \\
\text { a. } & \text { Implement } \\
& \text { mosque } \\
& \text { management } \\
& \text { IS } \\
\text { b. } & \text { Make } \\
& \text { innovative } \\
& \text { programs and } \\
\text { activities }\end{array}$ & $\begin{array}{ll}\text { Strategy W-O: } \\
\begin{array}{ll}\text { a. } & \text { Build } \\
& \text { mosque } \\
& \text { management } \\
& \text { IS } \\
\text { b. } & \text { Draft mosque } \\
& \text { business } \\
& \text { process SOP }\end{array}\end{array}$ \\
\hline $\begin{array}{l}\text { Threats (T): } \\
\text { a. Public } \\
\text { demand for } \\
\text { management } \\
\text { transparency } \\
\text { and } \\
\text { accountability } \\
\text { b. Low } \\
\text { participation } \\
\text { of teenagers in } \\
\text { mosque } \\
\text { activities }\end{array}$ & 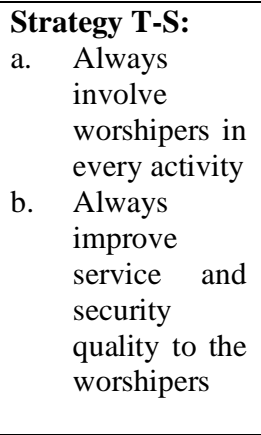 & $\begin{array}{l}\text { Strategy W-T: } \\
\text { a. Be consistent } \\
\text { in IT } \\
\text { application } \\
\\
\text { use } \\
\text { b. Always } \\
\\
\text { perform } \\
\text { evaluation }\end{array}$ \\
\hline
\end{tabular}

The critical success factor (CSF) method was carried out to examine the relationship between organizational business strategy and IS strategy. CSF helps IS strategic planning process focus on the strategic area, prioritize IS application suggestion, and evaluate IS strategy.

Table 2 Mosque Critical Success Factor

\begin{tabular}{|l|l|l|l|}
\hline No & Objective/Goal & $\begin{array}{l}\text { Critical Success } \\
\text { Factor } \\
\text { Candidate }\end{array}$ & $\begin{array}{c}\text { IS/IT } \\
\text { Requirement }\end{array}$ \\
\hline 1 & $\begin{array}{l}\text { Carry out every } \\
\text { procedure of } \\
\text { business } \\
\text { processes and } \\
\text { good } \\
\text { administration in }\end{array}$ & $\begin{array}{l}\text { Document } \\
\text { standardization } \\
\text { and control }\end{array}$ & $\begin{array}{l}\text { Document } \\
\text { control IS }\end{array}$ \\
\hline
\end{tabular}

\begin{tabular}{|c|c|c|c|}
\hline No & Objective/Goal & $\begin{array}{c}\text { Critical Success } \\
\text { Factor } \\
\text { Candidate }\end{array}$ & $\begin{array}{c}\text { IS/IT } \\
\text { Requirement }\end{array}$ \\
\hline & $\begin{array}{l}\text { an orderly } \\
\text { manner }\end{array}$ & & \\
\hline 2 & $\begin{array}{l}\text { Have sufficient } \\
\text { IS infrastructure }\end{array}$ & $\begin{array}{l}\text { Procurement of } \\
\text { facilities and } \\
\text { infrastructure in } \\
\text { accordance with } \\
\text { specified } \\
\text { requirements and } \\
\text { specifications }\end{array}$ & $\begin{array}{l}\text { Mosque asset } \\
\text { management } \\
\text { IS }\end{array}$ \\
\hline 3 & $\begin{array}{l}\text { Recruit } \\
\text { competent staff }\end{array}$ & $\begin{array}{l}\text { Quality human } \\
\text { resources }\end{array}$ & $\begin{array}{l}\text { Quality } \\
\text { recruitment } \\
\text { IS/IT }\end{array}$ \\
\hline 4 & $\begin{array}{l}\text { Build a good and } \\
\text { accountable } \\
\text { image }\end{array}$ & $\begin{array}{l}\text { Good } \\
\text { organizational } \\
\text { brand }\end{array}$ & $\begin{array}{l}\text { Web-based or } \\
\text { mobile IS to } \\
\text { promote } \\
\text { mosque } \\
\text { profile, } \\
\text { activities, and } \\
\text { services }\end{array}$ \\
\hline 5 & $\begin{array}{l}\text { Provide } \\
\text { responsive } \\
\text { service to the } \\
\text { community }\end{array}$ & Timely service & $\begin{array}{l}\text { Daily } \\
\text { operation IS }\end{array}$ \\
\hline 6 & $\begin{array}{l}\text { Create safe and } \\
\text { comfortable } \\
\text { mosque } \\
\text { environment }\end{array}$ & $\begin{array}{l}\text { Safe and } \\
\text { comfortable } \\
\text { mosque } \\
\text { environment }\end{array}$ & $\begin{array}{l}\text { Security, } \\
\text { monitoring, } \\
\text { and accident } \\
\text { response and } \\
\text { rescue IS/IT }\end{array}$ \\
\hline 7 & $\begin{array}{l}\text { Apply } \\
\text { comprehensive } \\
\text { IS/IT application }\end{array}$ & IS/IT application & $\begin{array}{l}\text { Infrastructure } \\
\text { for IS/IT } \\
\text { application }\end{array}$ \\
\hline
\end{tabular}

The next phase is existing application mapping to support organizational business processes. The existing applications are mapped into four quadrants (strategic, high potential, key operation, and support) according to the appraisal category of an application in terms of its impacts on business processes. The mapping results in the description of IS contribution to the business.

Table 3. Current Application Portfolio

\begin{tabular}{l|c|}
\hline \multicolumn{1}{c|}{ Strategic } & High Potential \\
\hline- & - \\
\hline $\begin{array}{l}\text { Public fund management } \\
\text { recording system } \\
\text { Key Operational }\end{array}$ & \\
\hline
\end{tabular}


It is suggested that there have been new IT development and improvement to the existing IT that has been implemented, but not optimally, in mosques. Therefore, it is necessary to synchronize the existing IS/IT with the new one. Table 4 presents the results of gap analysis of mosque management:

Table 4 Gap between the Proposed Application and the Existing Application

\begin{tabular}{|c|c|c|c|}
\hline No & $\begin{array}{l}\text { Business } \\
\text { requirement }\end{array}$ & Status & $\begin{array}{l}\text { Strategic } \\
\text { Planning } \\
\text { Decision }\end{array}$ \\
\hline 1 & $\begin{array}{l}\text { Decision } \\
\text { support } \\
\text { application }\end{array}$ & $\begin{array}{l}\text { Not } \\
\text { available }\end{array}$ & New System. \\
\hline 2 & $\begin{array}{l}\text { Quality } \\
\text { assurance } \\
\text { application }\end{array}$ & $\begin{array}{l}\text { Not } \\
\text { available }\end{array}$ & New System \\
\hline 3 & $\begin{array}{l}\text { Asset } \\
\text { manager } \\
\text { application }\end{array}$ & $\begin{array}{l}\text { Not } \\
\text { available }\end{array}$ & New System \\
\hline 4 & $\begin{array}{l}\text { Financial } \\
\text { application }\end{array}$ & Available & $\begin{array}{l}\text { Only recording } \\
\text { system. Upgrades } \\
\text { are required. }\end{array}$ \\
\hline 5 & $\begin{array}{l}\text { Activity } \\
\text { scheduling } \\
\text { application }\end{array}$ & $\begin{array}{l}\text { Not } \\
\text { available }\end{array}$ & New System \\
\hline 6 & $\begin{array}{l}\text { Website of } \\
\text { mosque } \\
\text { management }\end{array}$ & $\begin{array}{l}\text { Not } \\
\text { available }\end{array}$ & New System \\
\hline 7 & $\begin{array}{l}\text { Social media } \\
\text { application }\end{array}$ & $\begin{array}{l}\text { Not } \\
\text { available }\end{array}$ & New System \\
\hline 8 & $\begin{array}{l}\text { Archive } \\
\text { management } \\
\text { application }\end{array}$ & $\begin{array}{l}\text { Not } \\
\text { available }\end{array}$ & New System \\
\hline 9 & $\begin{array}{l}\text { Staffing } \\
\text { application }\end{array}$ & $\begin{array}{l}\text { Not } \\
\text { available }\end{array}$ & New System \\
\hline 10 & $\begin{array}{l}\text { CCTV } \\
\text { application }\end{array}$ & Available & $\begin{array}{l}\text { Upgrades and } \\
\text { integration with } \\
\text { other reporting } \\
\text { systems. }\end{array}$ \\
\hline 11 & $\begin{array}{l}\text { Emergency } \\
\text { evacuation } \\
\text { application }\end{array}$ & $\begin{array}{l}\text { Not } \\
\text { available }\end{array}$ & New System \\
\hline
\end{tabular}

Based on the results of the previous analysis, the strategic business planning and mosque information system for the next few years is presented in Table 5:

Table 5. Future Application Portfolio

\begin{tabular}{|c|c|}
\hline Strategic & High Potential \\
\hline $\begin{array}{ll} & \text { Social media } \\
\text { application } \\
\text { - } \quad \text { Mosque website }\end{array}$ & $\begin{array}{ll}\text { - } & \text { Decision support } \\
\text { application } \\
\text { - } & \text { Staffing } \\
\text { application } \\
\text { - } & \begin{array}{l}\text { Quality assurance } \\
\text { application }\end{array} \\
\end{array}$ \\
\hline $\begin{array}{ll}\text { - } & \text { Financial and } \\
\text { payroll } \\
\text { application } \\
\text { - Activity } \\
\text { scheduling } \\
\text { application }\end{array}$ & $\begin{array}{ll}\text { - } & \text { Asset manager } \\
\text { application } \\
\text { - } & \text { Archive } \\
\text { management } \\
\text { application } \\
\text { - } & \text { CCTV application } \\
\text { - } & \text { Emergency } \\
& \text { evacuation } \\
\text { application }\end{array}$ \\
\hline Key Operational & Support \\
\hline
\end{tabular}

\section{CONCLUSION}

Based on the result of the analysis of the strategic planning of information systems, it can be concluded that there are several applications necessary to be implemented in mosque management. These applications include two apps in the strategic quadrant, three applications in the high potential quadrant, two applications in the key operational quadrant, and four applications in the support quadrants. These applications are necessary to be implemented in mosque management to ensure the mosque's competitiveness and sustainability.

\section{REFERENCES}

G. A. F. Maulani and N. A. Hamdani, "Perencanaan Strategis Sistem Informasi pada Perguruan Tinggi Swasta di Indonesia ( Studi Kasus pada Institut Pendidikan Indonesia Garut )," J. PETIK, vol. 4, no. September, pp. 162 166, 2018, doi: https://doi.org/10.31980/jpetik.v4i2.367.

[2] F. N. Al-Aboud, "Strategic Information Systems Planning: A Brief Review," J. Inf. Process. Syst., vol. 11, no. 5, pp. 179-183, 2011, doi: 10.3745/JIPS.2010.6.1.121.

[3] G. Abdul Fatah Maulani, "PERENCANAAN STRATEGIS SISTEM INFORMASI MENGGUNAKAN BLUE OCEAN STRATEGY (STUDI KASUS PT. HERLINAH CIPTA PRATAMA : DODOL PICNIC)," STMIK LIKMI Bandung, 2015.

[4] A. Hamdani and G. A. Fatah, "Perencanaan 
Strategis Sistem Informasi pada Usaha Kecil dan Menengah," vol. 4, no. September, pp. 167-172, 2018.

[5] G. A. F. Maulani and N. A. Hamdani, "The Influence of Information Technology and Organizational Climate on the Competitiveness of Private Universities in Indonesia," Int. J. Recent Technol. Eng., vol. 8, no. 1S, pp. 142145, 2019, [Online]. Available: https://www.ijrte.org/download/volume-8issue-1s/.

[6] G. A. F. Maulani and N. A. Hamdani, "Can universities improve their competitiveness using information technology?," Int. J. Eng. Adv. Technol., vol. 8, no. 6 Special Issue 3, pp. 456-458, 2019 , doi: 10.35940/ijeat.F1083.0986S319.

[7] Muhlis, Sugiyo, T. Sumaryanto, and Kardoyo, "Planning for the Smart Mosque As Islamic Learning resources Center," Indones. J. Islam. Lit. Muslim Soc., vol. 1, no. 2, pp. 168-180, 2016, doi: 10.22515/islimus.v1i2.424.

[8] A. Ariyanto Rangga, D. B. Setyohadi, and A. J. Santoso, "Strategic planning of information system (case study: Ministry of religious affairs in Southwest Sumba)," Int. J. Comput. Eng. Inf. Technol., vol. 9, no. 7, pp. 143-149, 2017.

[9] I. S. Mohamed, N. H. A. Aziz, M. N. Masrek, and N. M. Daud, "Mosque Fund Management: Issues on Accountability and Internal Controls," Procedia - Soc. Behav. Sci., vol. 145, pp. 189-194, 2014, doi: 10.1016/j.sbspro.2014.06.026.

[10] M. F. B. A. Rahman, N. Mastuki, and S. N. S. Yusof, "Performance Measurement Model of Mosques," Procedia Econ. Financ., vol. 31, no. 15, pp. 26-35, 2015, doi: 10.1016/S22125671(15)01128-4.

[11] R. Ayu, "Ada 800 Ribu Masjid yang Terdaftar di Indonesia," http://www.tribunnews.com, 2018.

http://www.tribunnews.com/nasional/2018/11/ 10/wapres-jk-ada-800-ribu-masjid-yangterdaftar-di-indonesia.
[12] W. Khan, "Strategic Information Systems Planning (SISP) Practices In Health Care Sectors Of Bangladesh," Eur. Sci. J., vol. 12, no. 6, pp. 307-321, 2016, doi: 10.19044/esj.2016.v12n6p307.

[13] C. L. Wilkin and N. Cerpa, "Strategic Information Systems Planning: An Empirical Evaluation of Its Dimensions," J. Technol. Manag. Innov., vol. 7, no. 2, pp. 52-62, 2012, doi: 10.4067/S0718-27242012000200005.

[14] N. A. Hamdani, A. Solihat, and G. A. F. Maulani, "The Influence of Information Technology and Co-Creation on Handicraft SME Business Performance," Int. J. Recent Technol. Eng., vol. 8, no. 1S, pp. 151-154, 2019, [Online]. Available: https://www.ijrte.org/download/volume-8issue- $1 \mathrm{~s} /$.

[15] A. Hamdani, N.A dan Rhamdani, Manajemen Strategi, Edisi 1. Bandung: Karima, Bandung, 2019.

[16] Henderi, "Perencanaan Strategis SIstem Informasi Perguruan Tinggi," CommIT, vol. 3, no. 2, pp. 74-78, 2009.

[17] M. Informatika, P. M. Astra, K. Astra, I. Tbk, J. Gaya, and M. Raya, "Analisa Perencanaan Strategi Sistem Informasi Dan Teknologi Informasi ( $\mathrm{Si} / \mathrm{Ti}$ ) Dengan Menggunakan Framework Ward \& Peppard Di Perguruan Tinggi Abc," no. September, 2014.

[18] B. A. L. Lederer, "The Implementation of Strategic Information Systems Planning Methodologies," Strateg. Plan., vol. 2, no. September, pp. 445-461, 1988.

[19] H. E. Newkirk, A. L. Lederer, and C. Srinivasan, "Strategic information systems planning: Too little or too much?," J. Strateg. Inf. Syst., vol. 12, no. 3, pp. 201-228, 2003, doi: 10.1016/j.jsis.2003.09.001.

[20] A. A. Altameem, A. I. Aldrees, and N. A. Alsaeed, "Strategic Information Systems Planning ( SISP)," in Proceedings of the World Congress on Engineering and Computer Science, 2014, vol. I, pp. 22-24. 